\title{
EFFECTS OF IRRIGATION TECHNOLOGY ADOPTION ON FARMS PERFORMANCE IN ALGERIA: A STOCHASTIC FRONTIER PRODUCTION FUNCTION APPROACH
}

\author{
Amine OULMANE ${ }^{\text {* }}$ (iD, Amine M. BENMEHAIA
}

\author{
Address: \\ ${ }^{1}$ Research Centre in Applied Economics for Development (CREAD), Algeria \\ ${ }^{2}$ Department of Agricultural Sciences, University of Biskra, Algeria \\ * Corresponding author: a.oulmane@cread.dz
}

\begin{abstract}
The aim of this study is to evaluate the performance of water-saving technologies (WST) through an investigation of its effect at the farm level. Indeed, the study attempts to estimate the economic value of WST use in Algerian farming, through the comparison of some farm performance indicators between WST adopters, drip irrigation system as a WST, and farmers practicing gravity irrigation as a traditional system. A cross-section data from a survey is conducted in an irrigated perimeter situated in the north-eastern Algeria (Jijel region) encompassing 106 small horticultural farms (including 60 pepper producers and 46 tomato producers). First, the study compares some performance indicators between the two groups of farms. Second, a stochastic production frontier model is used to estimate the productivity gain generated by the WST adoption. Main results show that water consumption, gross margin, and water productivity are statistically significant between the two groups of farms. The average water productivity differential between WST users and non-users is $29 \%$ and $25 \%$ for tomato and pepper, respectively. The regression model has shown that increasing the WST use by $1 \%$ help to increase water productivity of the region by $0.20 \%$ for pepper production and $0.11 \%$ for tomato production. The findings of this study confirm the hypothesis that WST economize on water quantity, positively affects crop yield and can enhance water productivity.
\end{abstract}

Keywords: water-saving technologies, stochastic production function, irrigation, water productivity, Algeria JEL: Q25, Q15

\section{INTRODUCTION}

Investment in Water Saving Technologies (WST) was always considered as a solution to manage water demand. Indeed, the adoption of this technique allows the use of less water in the agricultural production process. For this reason, WST have been widely promoted in Algeria. However, little published research exists to support popular claims about their effectiveness in Algeria.

Algeria has a Mediterranean climate characterized by a long period of drought observed during the summer and a large seasonal and regional variability of precipitations. The important irregularity of rainfall accentuates the problem of water availability. Indeed, with nearly 292 $\mathrm{m}^{3} /$ Capita/year in 2014 , it is characterized by a very hard water stress, Algeria is thus more vulnerable than its neighbours Tunisia (420 $\mathrm{m}^{3} / \mathrm{cap} / \mathrm{year}$ ) and Morocco (879 $\mathrm{m}^{3} /$ cap/year) (FAO, 2017). The situation becomes even more complicated and the pressure on the resource will certainly increase in the next years because of the population growth, urban expansion, the improvement of living conditions, and the effects of climate change.

In Algeria, there is limited scope for further increase in the use of land in order to increase the production. According to Bellal (2011), the water resource shortage represents the main impediment for the intensification of Algerian agriculture. In fact, fresh water mobilization has reached its limit (Benblidia \& Thivet, 2010). Otherwise, many researches are showing that water is underpriced in the irrigated schemes of Algeria (Benmihoub \& Bedrani, 2011; Azzi et al., 2018; Oulmane et al., 2019). This leads to inefficient allocation of irrigation water by farmers and large loss of water. Therefore, future increases in irrigated production have to be originated from enhancing the productivity of farms.

Crop productivity has often been increased by adding inputs, including water, fertilizers and pesticides. However, these activities usually increase rather than reduce water use. It is therefore more rational to consider increasing crop productivity per unit water, which is generally termed water productivity. Thus, the key research question to ask here is the following: are WST allow to achieve the goal of increasing water productivity and reducing water consumption? Therefore, this work aims to estimate the economic value of WST use in the Algerian farming, through the comparison of some farm performance indicators between WST adopters, especially drip irrigation, and farmers practicing gravity irrigation. We also estimate a production function for the two groups of farmers in order to reveal the impact of WST adoption on water productivity in the study area. Although there has been little research done in the Algerian context.

Previous studies have been limited on the study of determinants of irrigation technology choice at the farm level (Salhi \& Bédrani, 2010; Belaidi, 2013; Benmehaia \& Brabez, 2017). 


\section{LITERATURE REVIEW ON WATER PRODUCTIVITY}

Comparison of the Water Productivity (WP) for different crops or different production process could be an interesting indicator to face the challenge of increasing food production with less water (Troy, 2012). Increasing WP is particularly appropriate where water is scarce compared with other resources involved in production. Reasons to improve agricultural water productivity include: i) to meet rising demands for food from a growing, wealthier, and increasingly urbanized population in light of water scarcity, ii) to respond to pressures to reallocate water from agriculture to cities and ensure that water is available for environmental uses, and (iii) to contribute to poverty reduction and economic growth (Molden et al., 2009).

It is well accepted that there is substantial scope to reduce irrigation water deliveries through a range of technical and management practices: drip and sprinkler irrigation, reduced allocations of water to farmers or pricing to influence demand. Many of these practices increase yields, and are important for water quality management and the overall control of water (Evans \& Sadler, 2008; Molden et al., 2009).

There is an emerging literature investigating the effects of irrigation efficiency improvements. Both theoretical modelling (Huffaker, 2008), and programming models or simulations (Peterson \& Ding 2005; Ward \& Pulido-Velazquez, 2008) show that more efficient irrigation may or may not reduce water use, depending on a variety of economic and hydrologic factors. In addition, not all water-saving technologies can achieve their expected levels of water saving after adoption. The effectiveness of water-saving technology also depends on factors such as farmers' skills in implementing technology and the production environment (e.g., soil characteristics).

Nowadays, the challenge for the agricultural sector is considerable, it needs to adapt in order to address the decline in the available volume of water for irrigation, while producing more. Partially, and in response to this challenge the Algerian government is encouraging the use of WST by farmers. These technologies are generally promoted as reducing the loss of water and enhancing water productivity (Sanz, 1999, Evans \& Sadler, 2008). Indeed, modernization of irrigation systems is considered as one of the technological options for increasing the efficiency of water use at the level of irrigated farms (Dinar \& Jammalamadaka, 2013). In addition, Letey $\boldsymbol{e t}$ al. (1990) report significant increases in crop yield and significant decreases in irrigation water use have been observed when pressurized irrigation systems (watering or drip irrigation) replace gravity irrigation methods. According to Playan \& Mateos (2006), these technologies not only save $48 \%$ to $67 \%$ of water but also reduce energy costs by $44 \%$ to $67 \%$ and from $29 \%$ to $60 \%$ of wages (Narayanamoorthy, 2009).

Another study, conducted by Dechmi $\boldsymbol{e t}$ al. (2003) in Northeastern Spain, shows that the efficiency of water use at the farm level is improved and reaches $90 \%$ in the case of sprinkler irrigation systems. The analysis of irrigation along the King Abdullah Canal in Jordan, by Battikhi \&
Abu-Hammad (1994), shows similar results, with greater irrigation efficiency from pressurized systems. These authors showed an improvement in efficiency by $30 \%$ compared to surface irrigation systems (not pressurized). However, these remain elusive in some cases. Improperly managed WST can be as wasteful and unproductive as poorly managed traditional systems (Perry et al., 2009, Benounich et al., 2014). When incorrectly applied, irrigation technology can cause losses arising on investments made by farmers, thus decreasing the economic water productivity and the overall sustainability (Battilani, 2012). Then, to gain the extra benefits of such technology, the most important is adequate system design, alongside proper installation, operation and maintenance, regardless of the irrigation method used (Hanson et al., 1995).

Furthermore, Salvador et al., 2011 compared various irrigation methods in Spain via the annual relative irrigation supply index (ARIS), i.e. a ratio of water applied versus water required. They found a greater efficiency of solid-set and drip irrigation systems than surface irrigation. Nevertheless, average annual figures conceal great variations in water applied to a given crop and irrigation efficiency at farm level, partly for lack of adequate knowledge. A remedy would be actions to improve farmers' water management via a combination of irrigation advisory services and policy measures'. Another study conducted in North China by Huang et al. (2017) describes the extent of water-saving technology usage and evaluates their impacts on water use, water productivity. Their results also show that using water saving technologies can reduce crop water use and improve the water productivity.

\section{DATA AND METHODS}

\section{Data and study area}

A cross-section data from 60 pepper producers and 46 tomato producers in the 2013-2014 period was collected from surveys conducted in an irrigated perimeter situated in the Northeastern Algeria. The total agricultural area is around 4885 ha. The irrigated area is about 2011 ha, representing $36 \%$ of the agricultural area. The area is characterized by small farms with the average size 2.6 ha, where $60 \%$ are equal to or less than 2 hectares. There is a low heterogeneity in the farm size (standard deviation of 2.24). In contrast, farms with an area at least equal to 5 ha represent $14 \%$ of the total number of farms but represent $38 \%$ of the area.

Thanks to the availability of water in the study area, several rotations can be grown during the year. The greenhouse crops are the most frequent in the region, they are practiced in more than $85 \%$ of the surveyed farms, with pepper and tomato as main crops under greenhouses. The open field is also present in $48 \%$ of the surveyed farms with cabbage as main winter crops, and watermelon and tomato as summer crops. The most widely used irrigation technique is drip irrigation system. It covers about $69 \%$ of the irrigated area. Irrigation by gravity system is a system used mostly for crops in greenhouses and cover $31 \%$ of the irrigated area. Each farmer can therefore use a combination of the two irrigation 
techniques based on the crops type.

\section{Water productivity measurement}

Water productivity concept aims to measure how a system converts water (associated with other resources) on products and services (Cai et al., 2011). It is defined as the ratio of agricultural output to the amount of water consumed (Molden et al., 2009). Thus, the Water Productivity $(W P)$ is computed as in Eq. 1.

$$
\begin{aligned}
& W P=\text { outcome from the use of water / } \\
& \text { water supply }
\end{aligned}
$$

The outcome can be measured in terms of physical mass (expressed in $\mathrm{kg}$ ) or in monetary value (local currency). The amount of water used is expressed in different ways according to the objectives, but also according to the availability of data: precipitation, withdrawal for irrigation, water supply to the plot or evapotranspiration (Troy, 2012). In our case, water productivity will be computed by considering the amount of water brought by the farmers, i.e., irrigation system.

\section{Estimation Methods}

In order to examine the effects of WST use for the main economic performances in the farm, we proceed an explanatory factorial analysis. A common method used in this case is a one-way analysis of variance. The performance index is considered as a quantitative dependent variable and the adoption as an explanatory factor, i.e. $x_{i}=f$ (irrigation systems). Results are evaluated by habitual tests. The differences express the effects of the WST in pepper and tomato production for the study region.

In order to reveal the impact of WST adoption, we use the production function approach. The stochastic production frontier model was first, and nearly simultaneously, elaborated by Meeusen \& Van den Broeck (1977) and Aigner et al. (1977), there has been considerable research to extend the model and explore exogenous influences on producer performance. Early empirical contributions (Schmidt \& Lovell, 1979, 1980, Kumbhakar et al., 1991) investigating the role of exogenous variables in explaining inefficiency effects. In this study, the evaluation of the economic cost of the WST use has been evaluated according to the theory of production. This technique seeks to approximate the water productivity gain generated by the use of the WST.

As for Fouzai et al. (2013), we assume that, for two groups of identical farms in terms of edaphic, climatic and socio-economic characteristics, but different in terms of irrigation techniques, the difference in productivity is calculated by the difference in the productivity according to water factor in each group of farmers. This approach then requires the estimation of a production function (Heady \& Shaw, 1954; Wampach, 1967; Cline, 1970; Hayami \& Ruttan, 1971; Lilyan \& Richard, 1998, Karagiannis et al., 2003) for the two irrigation techniques to measure the difference of the water productivity.

The production functions of the two groups of farms expressed in terms of a multiplicative error term (Eq. 2).
$P=X^{\alpha_{i}} e^{u-v}$

where $P$ represents farm yield, $X$ for a set of explanatory variables, $\alpha_{i}$ for parameters to be estimated, $u$ represents error term due to individual differences, and $v$ as stochastic disturbance having the habitual assumptions (i.i.d., with zero mean and constant variance). Similarly, water production function will be represented by Eq. 3 .

$W=X^{\beta_{i}} e^{u-v}$

where $W$ represents water productivity, $\beta_{i}$ for unknown parameters.

Explanatory variables used in this study are: the value of total fertilizer used, the value of labour (permanent and seasonal), the quantity of water consumed, and the variable costs. To reflect the effect of WST use on water productivity, a binary dummy variable was introduced as a regressor in the final equations. This dummy variable noted wst adoption, takes the value of 1 if the farmer uses WST, and 0 if he doesn't. The insertion of this dummy variable allows estimating the two models in the form of a single regression.

To be estimated, both models are used in terms of loglinear forms. The algebraic model is a stochastic linear Cobb-Douglas production function model. The log-linear form is commonly used in demand and production models (Griliches, 1964; Hayami \& Ruttan 1971). The loglinear form was considered as functional form for both equations. It allows for estimating coefficients that can be directly interpreted as elasticity.

\section{RESULTS AND DISCUSSION}

The descriptive approach of the question raised in this study could be illustrated by showing concretely the difference in irrigation water use. This could be done simply by plotting the water productivity variable factorized by crops and by WST adoption (Figure 1).

Figure 1 displays water productivity in both crops (pepper and tomato). The difference is evidently clear to the extent that tomato production presents higher water consumption by its nature, regarding the used farming practices (including irrigation systems). Furthermore, the difference is primarily due to the fact that tomato crop has significantly higher yields than pepper. On the other hand, Figure 1 also displays water productivity for irrigation systems (drip irrigation system as a WST taking the value of 1 , and gravity irrigation system as a traditional system taking a value of 0 ). The difference is remarkable. This means that, whatever the farming system considered, the WST presents higher levels of water productivity. From this fact, WST gains its superiority over traditional irrigation systems.

We examine first the effects of WST adoption in our case. The statistical comparison of economic performance between both groups of farming activities is presented in Table 1. We used one-way analysis of variance to highlight effects that make a statistically significant difference. 

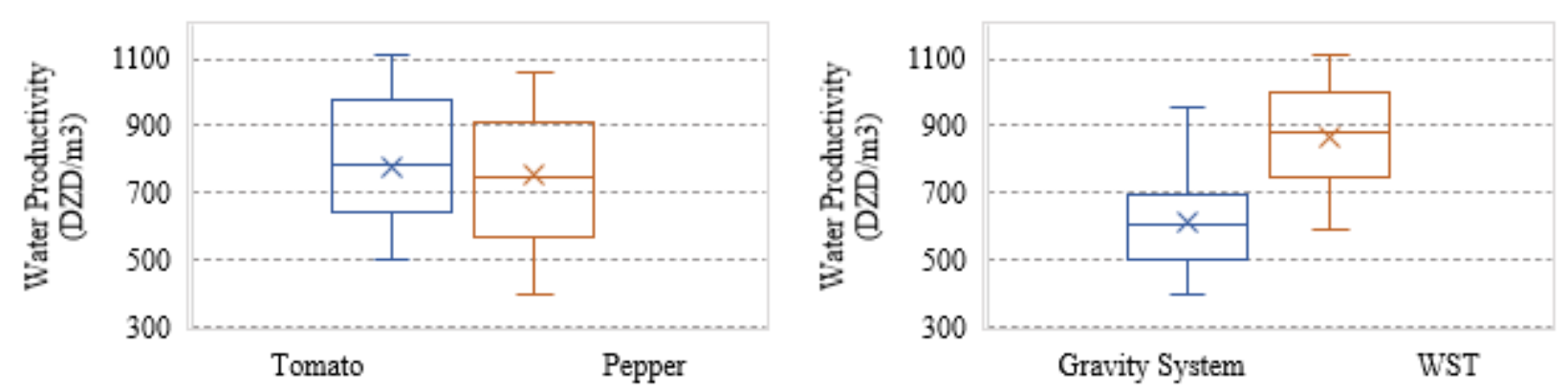

Figure 1. Water productivity in term of crop type (Left) and irrigation system (Right)

Table 1. Comparison of Performance Indices between WST Adopters and Gravity Irrigation Users

\begin{tabular}{|c|c|c|c|c|c|c|c|c|}
\hline & \multicolumn{3}{|l|}{ Tomato } & \multicolumn{3}{|l|}{ Pepper } & \multicolumn{2}{|l|}{ Average } \\
\hline & $\begin{array}{l}\text { WST } \\
\text { users }\end{array}$ & $\begin{array}{l}\text { Non } \\
\text { users }\end{array}$ & $\mathrm{t}$ & $\begin{array}{l}\text { WST } \\
\text { users }\end{array}$ & $\begin{array}{l}\text { Non } \\
\text { users }\end{array}$ & $\mathrm{t}$ & $\begin{array}{l}\text { WST } \\
\text { users }\end{array}$ & $\begin{array}{l}\text { Non } \\
\text { users }\end{array}$ \\
\hline Water consumption $\left(\mathrm{m}^{3} / \mathrm{ha}\right)$ & 3360 & 3840 & $.003 * *$ & 3136 & 3520 & $0.000 * *$ & 3248 & 3680 \\
\hline Fertilizer (DZD/ha) & 262608 & 228311 & $.030 *$ & 240544 & 212461 & $0.001 * *$ & 251576 & 220386 \\
\hline Labour (DZD/ha) & 711664 & 756032 & $.033 *$ & 703728 & 742304 & 0.679 & 731696 & 749168 \\
\hline $\begin{array}{l}\text { Variable costs } \\
\text { (DZD/ha) }\end{array}$ & 1633616 & 1526400 & .474 & 1509120 & 1460592 & 0.122 & 1571368 & 1493496 \\
\hline Yield (Kg/ha) & 94208 & 83600 & $.014 *$ & 66560 & 59600 & $0.044 *$ & & \\
\hline Gross margin (DZD/ha) & 1004208 & 814400 & $.032 *$ & 887040 & 685008 & $0.004 * *$ & 945624 & 749704 \\
\hline $\mathrm{WP}\left(\mathrm{DZD} / \mathrm{m}^{3}\right)$ & 785 & 610 & $.000 * *$ & 764 & 610 & $0.001 * *$ & 775 & 610 \\
\hline
\end{tabular}

Results from descriptive analysis show that using WST can lead to reduction in crop water and labour for both pepper and tomato producers. From the Table 1, the difference in terms of water used between WST users and non-users is statistically significant at $1 \%$. However, we note that the use of fertilizers is higher among WST users. This can be explained by the fact that farmers using drip irrigation system make fertigation. Therefore, they use water-soluble fertilizers which are more expensive. The average variable costs, represented by the cost of: water, fertilizers, labour, seeds and other intermediate consumption (mulching, greenhouse covers, and irrigation system), per hectare of WST users are 1633 and 1509 thousand DZD/ha, which are higher than the non-users variable costs, 1526 and 1460 thousand DZD/ha for tomato and pepper producers, respectively. However, the differences in terms of variable costs between both farms groups are not statistically significant.

The average yield of WST users and non-users are 94.2 and $83.6 \mathrm{~T} / \mathrm{ha}$ for tomato, and 66.6 and $59.6 \mathrm{~T} / \mathrm{ha}$ for pepper, respectively. The yield is around 8.4 and $7 \mathrm{~T} / \mathrm{ha}$ for tomato and pepper, respectively. The difference is statistically significant at 1 and 5\%. The gross margins obtained by WST users and non-users are, respectively, 1004 thousand and 814 thousand DZD/ha for tomato, and 887 thousand and 685 thousand DZD/ha for pepper. These results show that the average gross margin differential between WST users and non-users is, respectively, about $23 \%$ for tomato (190 thousand DZD/ha) and $29 \%$ for pepper (202 thousand DZD/ha). The difference is statistically significant at $5 \%$.

From Table 1, results also show that using WST improves productivity and allocation of irrigation water resources for both crops. In fact, differences between WST users and non-users regarding water productivity and water value are highly significant at $1 \%$ for both crops.

We turn now to the examination of the determinants of water productivity gain for both farming systems. Results of the estimation reveal some significant variables affecting the water productivity in study area. The results of the estimation by the method of ordinary least squares (OLS) for production function and water productivity are presented in Table 2.

The overall significance for the estimation performance is quite satisfying. The adjusted $\mathrm{R}^{2}$ and Fisher test are acceptable for all models, except for the tomato production function (fourth column), showing that the water productivity variations could relatively is explained by the regressed variables considered in our analysis.

We note that the specification adopted in this study is logarithmic. Given the statistic linear form of the model's equation, the elasticity of each explanatory variable calculated based on this model is equal to the slope of the corresponding function. Thus, obtained parameters are directly interpreted as elasticity.

According to Table 2, the coefficient estimates associated to water variable is negatively significant at $1 \%$ for both crops. The sign of this variable is explained by the fact that water and WP are negatively correlated. This coefficient is interpreted as the elasticity of water compared to the variable water productivity. When water increases by $1 \%$ WP decreases by $0.9 \%$. We notice that the fertilizer coefficient estimates for pepper is 0.16 with a statistical significance, whereas insignificant in tomato crop. This finding explains the fact that fertilizer and WP vary in the same direction. 
Table 2. Econometric Models of Production Functions and Water Productivity for Surveyed Farms

\begin{tabular}{|c|c|c|c|c|c|c|c|}
\hline \multirow{3}{*}{$\begin{array}{l}\text { Explanatory } \\
\text { Variables }\end{array}$} & \multicolumn{2}{|l|}{ Pepper } & \multicolumn{5}{|c|}{ Tomato } \\
\hline & \multirow{2}{*}{\multicolumn{2}{|c|}{$\begin{array}{l}\text { Farm } \\
\text { Production }\end{array}$}} & \multirow{2}{*}{\multicolumn{2}{|c|}{$\begin{array}{l}\text { Water } \\
\text { Productivity }\end{array}$}} & \multirow{2}{*}{$\begin{array}{l}\text { Farm } \\
\text { Production }\end{array}$} & \multirow{2}{*}{\multicolumn{2}{|c|}{$\begin{array}{l}\text { Water } \\
\text { Productivity }\end{array}$}} \\
\hline & & & & & & & \\
\hline \multirow[t]{2}{*}{ const. } & 5.80 & & 8.57 & $* *$ & 6.61 & 9.38 & $* *$ \\
\hline & (1.37) & & (2.03) & & (1.47) & (2.08) & \\
\hline \multirow[t]{2}{*}{ wst adoption } & 0.20 & & 0.20 & & 0.11 & 0.11 & \\
\hline & (3.30) & $* * *$ & (3.30) & $* * *$ & (1.39) & (1.39) & \\
\hline \multirow[t]{2}{*}{ water } & 0.02 & & -0.97 & $* * *$ & 0.09 & -0.90 & \\
\hline & $(0.20)$ & & $(-6.79)$ & & (0.59) & $(-5.96)$ & $* * *$ \\
\hline \multirow[t]{2}{*}{ fertilizer } & 0.16 & $* *$ & 0.16 & $* *$ & 0.01 & 0.01 & \\
\hline & (2.66) & & $(2.66)$ & & $(0.17)$ & $(0.17)$ & \\
\hline \multirow[t]{2}{*}{ labour } & 0.32 & $* * *$ & 0.32 & $* * *$ & 0.08 & 0.08 & \\
\hline & (3.10) & & (3.10) & & (1.17) & (1.17) & \\
\hline \multirow[t]{2}{*}{ variable costs } & 0.04 & & 0.04 & & 0.21 & 0.21 & \\
\hline & $(0.14)$ & & $(0.14)$ & & $(0.68)$ & $(0.68)$ & \\
\hline \multirow[t]{2}{*}{$\operatorname{csu}$} & 0.002 & $*$ & 0.002 & $*$ & 0.007 & 0.007 & \\
\hline & (1.89) & & (1.89) & & $(0.31)$ & $(0.31)$ & \\
\hline Observations & 60 & & 60 & & 46 & 46 & \\
\hline Adjusted $\mathrm{R}^{2}$ & 0.384 & & 0.739 & & 0.034 & 0.677 & \\
\hline Log-likelihood & 30.175 & & 30.175 & & 31.791 & 31.791 & \\
\hline $\mathrm{F}(6, \mathrm{~N})$ & 7.144 & $* * *$ & 28.940 & $* * *$ & 1.270 & 16.749 & $* * *$ \\
\hline
\end{tabular}

Note: *** significant at $1 \%$ level, ** significant at $5 \%$ and $*$ significant at $10 \% . \operatorname{csu}$ for cross-sectional units. The values of the $t$-ratio is in parentheses.

Therefore, when fertilizer increases by $1 \%$, WP increases by $0.16 \%$ in paper cropping, while without influence in tomato production.

The coefficient of the variable labor is 0.32 and is positively significant at the $1 \%$ in pepper production while it is not significant in tomato. This is explained by the fact that WP is positively affected by labor, i.e., when labor increases by $1 \%, W P$ increases by $0.32 \%$ without influence in tomato production. The elasticity of water productivity in relation with variable costs have lower values with no statistical significant in all models. This coefficient is positive according to the theory of economic but not significant for any interpretation. The parameter associated with the dummy variable wst adoption, which represents the used irrigation technique, is positive and highly significant for peppers' production function and its water productivity. Whereas, the tomato crop, both for production and water productivity functions, doesn't show any statistical significance. The sign of this variable confirms the hypothesis that a differential in water productivity exists and it is related to the use of the WST. This finding shows that the increase in the use of the WST by $1 \%$ generates a gain in water productivity by $0.2 \%$ in pepper production. Finally, the water variable shows a negative sign, and the labor with a positive sign. These corroborate our later findings on the differentials in farm performance regarding irrigation technology used. Consequently, WST enhance water productivity and economize water allocation, while it requires more labour. These findings confirm the hypothesis that WST economize on water quantity, it is labour-intensive technique, and it presents higher yields for both crops.

\section{CONCLUSIONS}

The Algerian's irrigation is characterized by a water use inefficiency essentially caused by the use of traditional irrigation techniques. This situation results in lower levels of yields and productivity. The main objective of this study is to describe the extent of water-saving technology adoption and evaluates their effects on water use and its productivity in small horticultural irrigated schemes (pepper and tomato crops) in the Northeastern Algeria. In this study, we compared the two groups using different irrigation techniques, the first using drip irrigation system as a WST, and the latter by the gravity irrigation system as a traditional system.

Contribution of each input to water productivity was also examined in this study. Findings indicate the relative importance of inputs contributing to water productivity. Therefore, we estimate the water production functions for the two groups of farmers by OLS for production functions.

The results show that water productivity has often been increased by adding inputs, including labour and fertilizers and it is negatively correlated to water quantity. This reflects the fact that farmers manage factors of production (labour, fertilizers and other inputs) to get better economic gains. These findings confirm the hypothesis that WST economize on water quantity, it is labour-intensive technique, and it presents higher yields for both crops. Our results show that using WST can enhance crop water allocation and positively affects crop yield and water productivity.

The results found are valuable for policy makers since they are enlightening the gain on water productivity in horticultural farms in Algeria. Then, the government should continue its efforts to promote and extend watersaving technologies. Increasing the adoption of such packages by farmers would be encouraged by credit access and enhancement of the extension and training services. As a continuity in this direction, research can be made in order to analyse changes in farmers' practices as a result of WST introduction. One such change is the use of 
different and improved varieties or crops that can be grown using these techniques. A concrete example for research in this direction is to analysis the expansion of the strawberry crops during the last decade in the irrigated perimeter studied.

\section{REFERENCES}

AIGNER, D., LOVELL, C.A.K., \& SCHMIDT, P. (1977). Formulation and Estimation of Stochastic Frontier Production Function Models. Journal of Econometrics, 6: 21-37. DOI: $\quad$ https://doi.org/10.1016/03044076(77)90052-5

AZZI, M., CALATRAVA, J., \& BEDRANI, S. (2018). Farmers' Willingness to Pay for Surface Water in the West Mitidja Irrigated Perimeter, Northern Algeria. Spanish Journal of Agricultural Research, 16(1): 1-16. DOI: https://doi.org/10.5424/sjar/2018161-12073.

BATTIKHI, A.M., \& ABU-HAMMAD, A.H. (1994). Comparison Between the Efficiencies of Surface and Pressurized Irrigation Systems in Jordan. Irrigation and Drainage $\quad$ Systems, $8(2)$ : $109-\quad 121$. DOI:https://doi.org/10.1007/BF00881179.

BATTILANI, A. (2012). Sustainable Knowledge-based Irrigation Management: The IRRINET Package.

BENBLIDIA, M., \& THIVET, G. (2010). Gestion des ressources en eau: Les limites d'une politique de l'offre. CIHEAM, 58.

BELAIDI, S. (2013). Les déterminants de choix de l'irrigation localisée par les Exploitants de la Mitidja. Les cahiers du CREAD, 103, 157-184.

BENMEHAIA, A.M., \& BRABEZ, F. (2017). The Socioeconomic Determinants of Asset Control Choices in Algerian Agriculture. Review of Agricultural and Applied Economics, 20(1): 20-24. DOI: $\underline{10.15414 / \mathrm{raae} / 2017.20 .01 .20-24}$

BENMIHOUB, A., \& BEDRANI, S. (2011). L'attitude des irrigants vis-à-vis de l'augmentation du tarif de l'eau: Cas d'un périmètre d'irrigation public en Algérie. Les Cahiers du CREAD, (98/99): 75-101.

BENOUNICHE, M., KUPER, M., \& HAMMANI, A. (2014). Mener le goutte à goutte à l'économie d'eau: ambition réaliste ou poursuite d'une chimère ? Alternatives Rurales. (2): $12 \mathrm{p}$.

CAI, X., MOLDEN, D., MAINUDDIN, M., SHARMA B., AHMAD M.D., \& KARIMI P. (2011). Producing More Food with Less Water in a Changing World: Assessment of Water Productivity in 10 Major River Basins. Water International, 36(1): 42-62. DOI: http://dx.doi.org/10.1080/02508060.2011.542403

CLINE, W. R. (1970). Economic Consequences of a Land Reform in Brazil. In: Economic Consequences of a Land Reform in Brazil. North-Holland Publishing Company.

DECHMI, F., PLAYÁN, E., FACI, J. M., \& TEJERO, M. (2003). Analysis of an Irrigation District in Northeastern Spain: I. Characterisation and Water Use Assessment. Agricultural Water Management, 61(2): 75-92. DOI: https://doi.org/10.1016/S0378-3774(03)00020-9

DINAR A., \& JAMMALAMADAKA U.K. (2013). Adaptation of Irrigated Agriculture to Adversity and Variability Under Conditions of Drought and Likely Climate Change: Interaction Between Water Institutions and Social Norms. International Journal of Water Governance, 1: 41-64.

EVANS, R.G., \& SADLER, E.J. (2008). Methods and Technologies to Improve Efficiency of Water Use. Water resources research, 44(7). DOI: https://doi.org/10.1029/2007WR006200

FAO

http://www.fao.org/nr/water/aquastat/countries_regions/d za/indexfra.stm

FOUZAI, A., BACHTA, M.S., BEN BRAHIM, M., \& RAJHI, E. (2013). Evaluation économique de la dégradation de l'eau d'irrigation Etude de cas : La région de Korba. In $A A A E$ Fourth International Conference, September 22-25, 2013, Hammamet, Tunisia (No. 160683).

GRILICHES, Z. (1964). Research expenditures, education, and the aggregate agricultural production function. The American Economic Review, 961-974. DOI: http://www.jstor.org/stable/1809481

HANSON, B., BOWERS, W., \& DAVIDOFF, B. (1995). Field Performance of Micro-irrigation Systems. In: Microirrigation for a Changing World, Proceedings of Fifth International Micro-irrigation Congress, April 2-6, 1995. American Society of Agricultural Engineers, Orlando, FL, 769-774.

HAYAMI, Y., \& RUTTAN, V.W. (1971). Agricultural Development: An International Perspective. The Johns Hopkins Press.

HEADY, E., \& SHAW, R. (1954). Resources Returns and Productivity Coefficients in Selected Farming Areas. Journal of Farm Economics, 36: 243-257. DOI: https://doi.org/10.2307/1233073

HUANG, Q., WANG, J., \& LI, Y. (2017). Do Water Saving Technologies Save Water? Empirical Evidence from North China. Journal of Environmental Economics and Management, 82: 1-16. DOI: https://doi.org/10.1016/j.jeem.2016.10.003

HUFFAKER, R. (2008). Conservation Potential of Agricultural Water Conservation Subsidies. Water Resources Research, 44: 1-8. DOI: https://doi.org/10.1029/2007WR006183

KARAGIANNIS, G., TZOUVELEKAS, V., \& XEPAPADEAS, A. (2003). Measuring Irrigation Water Efficiency with a Stochastic Production Frontier. Environmental and resource economics, 26(1): 57-72. DOI: https://doi.org/10.1023/A:1025625402762

KUMBHAKAR, S. C., GHOSH, S., \& MCGUCKIN, J. T. (1991). A Generalized Production Frontier Approach for Estimating Determinants of Inefficiency in US Dairy Farms. Journal of Business \& Economic Statistics, 9(3): 279-286.

DOI:

http://dx.doi.org/10.1080/07350015.1991.10509853

LETEY, J., DINAR, A., WOODRING, C., \& OSTER, J. D. (1990). An Economic Analysis of Irrigation Systems. Irrigation Science, 11(1): 37-43. DOI: https://doi.org/10.1007/bf00189993

LILYAN E. F., \& RICHARD K.P. (1998). Agricultural Productivity in Developing Countries. Agricultural Economics, 19: 45-51. DOI: https://doi.org/10.1016/S0169-5150(98)00045-0

MEEUSEN, W., \& VAN DEN BROECK, J. (1977). Efficiency Estimation from Cobb-Douglas Production 
Function with Composed Error. International Economic Review, 18: 435-44. DOI: 10.2307/2525757

MOLDEN, D., OWEIS, T., STEDUTO, P., BINDRABAN, P., HANJRA, M. A., \& KIJNE, J. (2009). Improving Agricultural Water Productivity: Between Optimism and Caution. Agricultural Water Management, 97(4): $\quad 528-535$.

DOI: https://doi.org/10.1016/j.agwat.2009.03.023

BELLAL, S. A. (2011). Ressources, usagers et gestionnaires de l'eau en zone semi-aride: le cas des plaines littorales oranaises (Ouest algérien). Insaniyat/إنسانيات. Revue algérienne d'anthropologie et de sciences sociales, (53), 167-175. DOI: $10.4000 /$ tem.2859

NARAYANAMOORTHY, A. (2008). Water-saving technologies as a demand management option: potentials, problems and prospects. Strategic Analyses of the National River Linking project (NRLP) of India: Promoting Irrigation Demand Management in India: Potentials, Problems, and Prospects, 3, 93.

OULMANE A., FRIJA A. \& BRABEZ F. (2019). Modelling Farmers' Responses to Irrigation Water Policies in Algeria: An Economic Assessment of Volumetric Irrigation Prices and Quotas. Irrigation and Drainage. DOI: https://doi.org/10.1002/ird.2327

PERRY, C., STEDUTO, P., ALLEN, R.G., \& BURT, C.M. (2009). Increasing Productivity in Irrigated Agriculture: Agronomic Constraints and Hydrological Realities. Agricultural Water Management, 96(11): 15171524. DOI: https://doi.org/10.1016/j.agwat.2009.05.005 PETERSON, J.M., \& DING, Y. (2005). Economic Adjustments to Groundwater Depletion in the High Plains: Do Water-Saving Systems Save Water? American Journal of Agricultural Economics, 87: 148-160. DOI: https://doi.org/10.1111/j.0002-9092.2005.00708.x

PLAYAN, E., \& MATEOS, L. (2006). Modernization and Optimization of Irrigation Systems to Increase Productivity. Agricultural Water Management, 80: 110116. DOI: https://doi.org/10.1016/j.agwat.2005.07.007
SALVADOR, R., MARTÍNEZ-COB, A., CAVERO, J., \& PLAYÁN, E. (2011). Seasonal On-Farm Irrigation Performance in the Ebro Basin (Spain): Crops and Irrigation Systems. Agricultural Water Management, 98: 577-587.

DOI:

https://doi.org/10.1016/j.agwat.2010.10.003

SANZ, G.L. (1999). Irrigated Agriculture in the Guadiana River High Basin (Castilla-La Mancha, Spain): Environmental and Socioeconomic Impacts. Agricultural Water Management, 40(2): 171-181. DOI: https://doi.org/10.1016/S0378-3774(98)00119-X

SALHI, S., \& BEDRANI, S. (2010). Reconversion au goutte-à-goutte : les limites du PNDA. In: IMACHE, A., HARTANI, T., BOUARFA, S., \& KUPER, M. La Mitidja 20 ans après : réalités agricoles aux portes d'Alger. Alger: éditions Alpha.

SCHMIDT, P., \& LOVELL, C. A. K. (1979). Estimating Technical and Allocative Inefficiency Relative to Stochastic Production and Cost Frontiers. Journal of Econometrics, 9: 343-66. DOI: https://doi.org/10.1016/0304-4076(79)90078-2

SCHMIDT, P., \& LOVELL, C. A. K. (1980). Estimating Stochastic Production and Cost Frontiers When Technical and Allocative Inefficiency Are Correlated. Journal of Econometrics, $\quad$ 13: 83-100. DOI: https://doi.org/10.1016/0304-4076(80)90044-5

TROY, B. (2012). Augmenter la productivité de l'eau: un objectif de développement agricole? Notes, 2.

WAMPACH, J. P. (1967). Les sources des différences interrégionales de productivité du travail agricole, une analyse économétrique, Québec, Ontario, 1951 et 1961. (Ph-D Dissertation, Université de Laval).

WARD, F. A., \& PULIDO-VELAZQUEZ, M. (2008). Water Conservation in Irrigation Can Increase Water Use. Proceedings of the National Academy of Sciences 105(47), 18215-18220. DOI: https://doi.org/10.1073/pnas.0805554105 